\title{
Optimization system at Vehicle Control Department for the control and management of the company's vehicles
}

\section{Sistema de optimización en el departamento de Control Vehicular para el control y manejo de los vehículos de la empresa}

SANTOS-OSORIO, René*†, LÓPEZ-RIVERA, José Armando, LÓPEZ-ÁNGELES, Dora Lilia and RODRÍGUEZ-MIRANDA, Gregorio

Universidad Tecnológica de San Juan del Río

ID $1^{\text {st }}$ Author: René, Santos-Osorio / ORC ID: 0000-0002-4411-7628, Researcher ID Thomson: G-3453-2019, CVU CONACYT ID: 619722

ID $1^{\text {st }}$ Coauthor: José Armando, López-Rivera / ORC ID: 0000-0002-3821-3058

ID $2^{\text {nd }}$ Coauthor: Dora Lilia, López-Ángeles / ORC ID: 0000-0001-7608-9169, Researcher ID Thomson: G-3474-2019, CVU CONACYT ID: 672135

ID $3^{\text {rd }}$ Coauthor: Gregorio, Rodríguez-Miranda / ORC ID: 0000-0002-2512-892X, Researcher ID Thomson: S-5808-2018, CVU CONACYT ID: 246718

DOI: 10.35429/JEDT.2019.4.3.7.14

Received March 28, 2019; Accepted June 20, 2019

\begin{abstract}
This project proposes a solution to an internal problem of an organization when managing its vehicles. A web system will be developed for the control and management of information, procedures and functions of the company's vehicles in an efficient way and thus have a better development optimizing times. The objective is to facilitate the management of information, improving the control of activities, internal functions and support, in order to speed up processes through the use of the computer system. The methodology to be used is Scrum, since it provides optimal options, such as Sprint, work boards at a certain time for the development and proper functioning of the system, as well as constant revision, avoiding errors and improving development times. The Scrum methodology provides an agile process to develop software; it was first applied by Ken Schwaber and Jeff Sutherland, who documented it in detail in the book Agile Software Development with Scrum.

1. To analyze and investigate the different development tools.

2. To select the tools that generate the greatest advantages for the project.

3. To make a work plan for the implementation of the System.

4. To perform tests and carry out adjustments for the final implementation.
\end{abstract}

Vehicle control, Computer system, Automation

\begin{abstract}
Resumen
El presente proyecto propone una solución a un problema interno de una organización al momento de administrar sus vehículos. Se elaborará un sistema web, para el control y manejo de información, procedimientos y funciones de los vehículos de la empresa, de una manera eficaz y así tener un mejor desarrollo optimizando tiempos. El objetivo es facilitar el manejo de información, mejorando el control de actividades, funciones internas y de apoyo para con ello poder agilizar procesos mediante el uso del sistema informático. La metodología a utilizar es Scrum, ya que proporciona opciones óptimas, como los Sprint, juntas de trabajo en determinado tiempo para el desarrollo y buen funcionamiento del sistema, constante revisión, evitar errores y mejorar tiempos de desarrollo. La metodología Scrum proporciona un proceso ágil para desarrollar software que fue aplicado por primera vez por Ken Schwaber y Jeff Sutherland., quienes lo documentaron en detalle en el libro Agile Software Development with Scrum.

1. Analizar e investigar las diferentes herramientas de desarrollo.

2. Seleccionar las herramientas que generen mayores ventajas para el proyecto.

3. Realizar un plan de trabajo para la implementación y puesta en función del Sistema.

4. Realizar pruebas y llevar a cabo los ajustes para la implementación definitiva.
\end{abstract}

Control vehicular, Sistema informático, Automatizacióz

Citation: SANTOS-OSORIO, René, LÓPEZ-RIVERA, José Armando, LÓPEZ-ÁNGELES, Dora Lilia and RODRÍGUEZMIRANDA, Gregorio. Optimization system at Vehicle Control Department for the control and management of the company's vehicles. Journal-Economic Development Technological Chance and Growth. 2019. 3-4: 7-14.

\footnotetext{
* Correspondence to Author (email: rsantoso@utsjr.edu.mx)

$\dagger$ Researcher contributing first author.
} 


\section{Introduction}

The primary objective of the research was the benefit of the company, specifically, by proposing a solution to an internal problem of organization regarding the administration of its vehicles, such as expediting and facilitating the work of the Vehicle Control Department. Web systems, also known as web applications, are created and installed on a platform or operating systems (Windows, Linux), or they can be hosted on an Internet server or on an intranet (local network) (Web, 2019).

Web systems have very powerful functionalities that provide answers to particular cases; they can be used in any web browser (Chrome, Firefox, Internet Explorer, etc.) regardless of the operating system. To use the web applications it is not necessary to install them on each computer, since users connect to a server where the system is hosted.

Web applications work with databases that allow processing and displaying information dynamically for the user, saving costs, time and human resources.

There are currently several software development tools that allow the implementation of a Computer System. Therefore, it was necessary to determine the most appropriate option for the company that needs to manage its vehicles efficiently and in an organized manner.

\section{Methodology}

According to the Scrum methodology, the activities to be carried out were:

\section{Analyzing and investigating the different development tools.}

\section{a. Java}

It is a general purpose, concurrent, objectoriented programming language that was specifically designed to have as few implementation dependencies as possible. Its intention is to allow application developers to write the program once and execute it on any device, which means that the code that is executed on one platform does not have to be recompiled to run on another.
Java is, as of 2012, one of the most popular programming languages in use, particularly for client-web server applications, with about ten million users reported.

Renowned for its readability and simplicity, Java is one of the most adopted programming languages: more than 9 million developers use it and it is present in 7 billion devices worldwide. Since 2001, it remains in the top positions, reaching second place as the lowest in March 2015. (Java, 2019)

\section{b. C}

It is a programming language originally developed by Dennis Ritchie, between 1969 and 1972, at Bell Laboratories, 1 as an evolution of the previous B language, in turn based on BCPL. Like $B$, it is a language oriented to the implementation of operating systems, specifically Unix. $\mathrm{C}$ is appreciated for the efficiency of the code it produces and is the most popular programming language for creating systems software, although it is also used to create applications.

It is a language of static data types, weakly typified, of medium level, since it has the typical structures of high-level languages but, in turn, it has language constructions that allow very low level control. Compilers often offer extensions to the language, which provides the possibility to mix assembly code with $\mathrm{C}$ code or directly access memory or peripheral devices. (C, 2019)

\section{c. $\mathrm{C}++$}

$\mathrm{C}++$ is a programming language designed in 1979 by Bjarne Stroustrup. The intention was to extend the programming language $\mathrm{C}$ with mechanisms that allow the manipulation of objects. In that sense, from the point of view of object-oriented languages, $\mathrm{C}++$ is a hybrid language.

Subsequently, generic programming facilities were incorporated, which added to the paradigms of structured programming and object-oriented programming. This is why it is often said that $\mathrm{C}++$ is a multiparadigm programming language. 
There is currently a standard, called ISO $\mathrm{C}++$, to which the most modern compiler manufacturers have adhered. There are also some interpreters, such as ROOT.

A particularity of $\mathrm{C}++$ is the possibility of redefining operators, and of being able to create new types that behave as fundamental types. The name "C++" was proposed by Rick Mascitti in 1983, when the language was first used outside a scientific laboratory. The name "C with classes" had been used before. In $\mathrm{C}++$, the expression " $\mathrm{C}++$ " means "increase in $\mathrm{C}$ " and implies that $\mathrm{C}++$ is an extension of $\mathrm{C} .(\mathrm{C}++$, 2019)

\section{d. Python}

Python is an interpreted programming language, the philosophy of which emphasizes a syntax that favors readable code. It is a multiparadigm programming language, since it supports object orientation, imperative programming and, to a lesser extent, functional programming. It is an interpreted language which uses dynamic typing and is multiplatform.

It is managed by the Python Software Foundation. It has an open source license, called Python Software Foundation. (Python, 2019)

\section{e. JavaScript}

JavaScript (commonly abbreviated JS) is an interpreted programming language, dialect of the ECMAScript standard. It is defined as objectoriented, prototype-based, imperative, weakly typed and dynamic.

It is mainly used in its client-side form, implemented as part of a web browser allowing improvements in the user interface and dynamic web pages, although there is a form of serverside JavaScript (Server-side JavaScript or SSJS). Its use in external applications to the web, for example in PDF documents, desktop applications (mostly widgets) is also significant. Since 2012, all modern browsers fully support ECMAScript 5.1, a javascript version. Older browsers support at least ECMAScript 3. The sixth edition was released in July 2015.5 JavaScript was designed with a syntax similar to $\mathrm{C}$, although it adopts names and conventions of the Java programming language. However, Java and JavaScript have different semantics and purposes. (Javascript, 2019).

\section{f. PHP}

PHP, recursive acronym for Hypertext Preprocessor, is a general-purpose programming language of server-side code originally designed for dynamic web content development. It was one of the first server-side programming languages that could be incorporated directly into an HTML document, instead of calling an external file that processed the data. The code is interpreted by a web server with a PHP processor module that generates the resulting HTML.

PHP has evolved, so it includes now a command line interface that can be used in separate graphic applications. It can be used on most web servers, as well as on many operating systems and platforms for free. (PHP, 2019)

\section{g. Laravel}

Laravel is an open source framework for developing web applications and services with PHP 5 and PHP 7. Its philosophy is to develop PHP code in an elegant and simple way, avoiding "spaghetti code." It was created in 2011 and has a great influence of frameworks.

Laravel aims to be a framework that allows the use of an elegant and expressive syntax to create code easily and allowing a multitude of functionalities. It aims to take advantage of the best of other frameworks and the features of the latest versions of PHP.2

Much of Laravel is made up of dependencies, especially Symfony, this implies that Laravel's development also depends on the development of its dependencies.

\section{Characteristics}

$\begin{array}{ll}- & \text { Routing system, also RESTful } \\ - & \text { Blade, Template Engine } \\ - & \text { Fluent Petitions } \\ - & \text { Eloquent ORM } \\ - & \text { Composer based } \\ - & \text { Cache support } \\ - & \text { MVC support } \\ - & \text { Uses Symfony components }\end{array}$

SANTOS-OSORIO, René, LÓPEZ-RIVERA, José Armando, LÓPEZÁNGELES, Dora Lilia and RODRÍGUEZ-MIRANDA, Gregorio. Optimization system at Vehicle Control Department for the control and management of the company's vehicles. Journal-Economic Development Technological Chance and Growth. 2019 


\section{Selecting the tools that generate the greatest advantages for the project}

We chose to work with PHP and its development tool Laravel since it is a development framework that offers great benefits because it already brings developed code and methods; it also adapted to the type of system that was required in the department.

Laravel adapts to the development of complex projects and must be developed in a short time, works with the view-controller model, Model, Controller and View web that will be shown to the User. Besides, Laravel already includes its own template engine (Blade) with which it is easier to make forms and web design of the system. (Laravel, 2019)

\section{Work plan for the implementation and commissioning of the System (SICOVE)}

In January 2019, we identified that the company did not have a computer system that expedited and facilitated the work of the Vehicle Control Department, so the project titled "Vehicle Control System" (SICOVE, for its acronym in Spanish) was put into operation. It began with the planning stage, in which the people of the department discussed about the exact and precise requirements of the system.

The project started in the month of January, it was formally established at the end of the same month with the exact requirements and it was until the end of March when the first tests of the developed system we conducted, along with the Database.

\section{Tests and adjustments for final implementation}

The SICOVE was installed on a DELL server with the following characteristics:

CentOS 7 64-bit operating system, processor speed of $2.40 \mathrm{Ghz}$, 4Cores per processor, $12 \mathrm{~Gb}$ of DDR3 RAM, and an Apache server. The CentOS 7 operating system is used professionally in the industry and in different projects, the current version 7.0 of CentOS (January 2017) is based on the Linux 3.10.0 kernel, including the security extension mentioned above, SELinux, and has implemented GCC (GNU Compiler Collection).
This collection contains the compiler for the most important programming languages, such as $\mathrm{C}, \mathrm{C}++$ and Java.

This Linux distribution is also compatible with Hyperthreading (splitting a processor into two virtual processors to increase performance), Plug and Play, Bluetooth and the sixth version of the Internet protocol (IPv6). For previous versions of CentOS 5 and 6 there are compatibility libraries. The standard distribution package also includes the following software components:

$\begin{array}{ll}- & \text { Web server: HTTP 2.4.6 (Apache) } \\ - & \text { LAN Manager: Samba-4.1.x } \\ - & \text { Database: MariaDB 5.5.x, PostgreSQL } \\ & \text { 9.2.x } \\ -\quad & \text { Script language: PHP 5.4, Python 2.7, } \\ & \text { Perl 5.16.3 } \\ -\quad & \text { Desktop interface: Gnome 3.14, KDE } \\ & \text { 4.14 } \\ -\quad & \text { Screen server: X.org 7.7 } \\ -\quad & \text { Email client: Evolution } 3.12, \\ & \quad \text { Thunderbird 45 } \\ -\quad & \text { Web browser: Firefox 45 } \\ - & \text { Office Suite: LibreOffice 4.3.7 }\end{array}$

As a web server, we have Apache Tomcat Glasfish, among the best known, and with its own technologies. But the one that best suits this project and the most appropriate technologies is Apache Tomcat.

The SICOVE documentation for the development and implementation of the Vehicle Control System states that tests were carried out during the development of the system to verify its operation and thus be able to continue advancing in the system.

A first test was conducted verifying that there was a connection between the system development environment (Laravel) and the database (MySQL), to be able to use, handle and manipulate information correctly in the system, obtaining a good connection between the two parties.

A second test was carried out to verify the user validation functionality (LOGIN) at the time of logging into the system with email and password; for this purpose, manual information was filled out in the respective user database, so that they could access or test their access to the system.

SANTOS-OSORIO, René, LÓPEZ-RIVERA, José Armando, LÓPEZÁNGELES, Dora Lilia and RODRÍGUEZ-MIRANDA, Gregorio. Optimization system at Vehicle Control Department for the control and management of the company's vehicles. Journal-Economic Development Technological Chance and Growth. 2019 
The third test was to verify that the insertion, edition and elimination of users worked correctly, saving and making changes in the database, from the execution of the system, obtaining correct results. The next step was to assess the correct operation of the vehicles with the other related categories; in order to control its functions, insertion, modification and elimination were evaluated.

The following test was to verify that the correct insertion and upload of the files was carried out in the different models related to vehicles and users, such as circulation cards, invoice letters, insurance policies, driver's licenses among other models, in order to show the files correctly. Once the test was conducted correctly, the next stage was the elimination and modification (Changing the file) of the models and the information update into the database.

The final test was carried out once the system was implemented on the server with the CentOS 7 operating system and connected to the company's internal network, in order to access the system from any part of the company. We checked that the system worked correctly and executed all the functions without presenting any error.

\section{Results}

The system was completed to $85 \%$, since it correctly executes all the functions specified in the requirements and does not present any more execution errors; however, the remaining $15 \%$ corresponds to design adjustments and to the addition of other options that will facilitate the interaction with the user. The system is able to control and manipulate information from Users, Driver's Licenses, Vehicles, Suppliers, Business Units, Types of Vehicles, Sub Types of Vehicles, Holdings, Circulation Cards, Invoice Letters, Insurance Policies and Vehicle Conditions without errors.

The system was finished until the implementation within the company network; the result of the implementation is reflected in the internal address of the company: http: // dquserver02: 8585 / psycho /.

\section{Conclusions}

With the implementation of the Vehicle Control System (SICOVE), it was found that the proposal for the solution to the internal problem of organization to manage vehicles achieved its purpose by expediting the handling of vehicle information. The system is quite functional and reduces the time for the administration of vehicles, it helps the Vehicle Control Department to carry out its activities and functions with greater order, and in a more efficient way.

The development of this system was quite good, because it not only benefited the area of Vehicle Control, but also the different departments of the company. In addition, many activities were implemented, which increased the knowledge and experience in the development of a project or system. As a result of the development of this project, other outcomes were obtained for the benefit of the people involved.

For example, we mentioned that new things were put into practice and that had to be investigated, analyzed and tested in order to use them. The people involved also learned to provide solutions to some processes that originated within the company's facilities, as well as to develop, implement and manage systems or application software that meets quality standards in order to support the productivity and competitiveness of organizations for good efficiency.

\section{References}

AMPARAN-DURAN, Rafael Gibrán. Desarrollo de aplicación web con herramientas MEAN para el procesamiento y comunicación de información de estudiantes en la UT de Puerto Peñasco. Revista de Sistemas Computacionales y TIC'S 2017, 3-7: 7-12.

ARROYO, Jorge, GONZALES, Florentino, GASPAR, Beatriz y REYES, Matilde. Implementación de conmutador telefónico Institucional en la UTXJ, utilizando Software Libre. Revista de Aplicación Científica y Técnica ECORFAN, , 3, 16-21. From ECORFAN Database. 
Ataupillco, Q., \& Noemy, A. (2019). Implementación del control interno para consolidar la correcta administración en la división de licencias de conducir de la Dirección Regional de Transportes y Comunicaciones Ayacucho, 2017.

BAEZ-IBARRA, Alejandro, ARELLANESCANCINO, Nimcy y SOSA-PERDOMO, Amparo. Efectividad de la aplicación de metodologías ágiles para el desarrollo de apps móviles. Un caso de estudio. Revista de Sistemas Computacionales 2016, 2-6: 45-66.

C. (18 de 04 de 2019). Retrieved from https://www.ecured.cu/C_(lenguaje_de_progra maci\%C3\%B3n)

C++. (14 de 04 de 2019). Retrieved from https://www.ecured.cu/C\%2B\%2B

Castillo, C., Gaby, M., \& Mío Carrasco, J. (2019). Análisis del sistema de control interno para contribuir a la gestión administrativa de la empresa Comercio \& Cía. SA, en JaenCajamarca 2016.

D. Robles, P. Ñañez y N. Quijano. "Control y simulación de tráfico urbano en Colombia: Estado del arte". Revista de Ingeniería Universidad de los Andes. $\mathrm{N}^{\circ}$ 29, pp. 5969. 2009.

Davila Miranda, J. R. (2019). Diseño de un prototipo electrónico utilizando sensores acelerómetro y giroscopio para optimizar el control de velocidad y estabilidad dinámica de un vehículo.

European Symposium on Computer Modeling and Simulation (4th), IEEE Computer Society, USA (2010), pp. 541-54 (Washington D.C), 17-19 Nov, 2010.

GARCÍA-JIMÉNEZ, Omar, SERNAENCINAS, María, VALENCIA-PALOMO, Guillermo y ROSEGÓMEZ César. Interfaz gráfica de planeación de la trayectoria de un vehículo aéreo no tripulado. Revista de Sistemas Computacionales y TIC'S 2017, 3-10: 50-57.
GONZÁLEZ-SILVA, Marco Antonio, FRANCO-MORENO, Juan José, REYESNEGRETE, Daniel Ignacio, BARRERABAUTISTA, Nelida Yulini. Sistema de control de información y recursos para proyectos en desarrollo. Revista de Sistemas Computacionales y TIC'S 2017, 3-8:10-19.

Gutiérrez, S., \& Francisco, S. (2019). Caracterización del control interno administrativo en las empresas envasadoras y comercializadoras de gas licuado de petróleo del Perú. Caso: Piura GasSAC-Piura, 2017.

HERRERA-RODRÍGUEZ, Eloína, LOPEZRODRÍGUEZ, Sonia, MORENO-MORENO, Ricardo y HERNÁNDEZMÁRQUEZ, Yesenia. Uso de las Tics como método para elaborar trabajo Recepcional y automatización de formatos de estadías (F-DV-007 y F-DA-029), aula virtual y plataforma de generación de formatos digitales. Revista de Sistemas Computacionales y Tics. 2018, 4-11: 9-16.

Java. (18 de 04 de 2019). Retrieved from https://www.java.com/es/download/faq/whatis_ java.xml

Javascript. (15 de 05 de 2019). Retrieved from http://www.maestrosdelweb.com/que-esjavascript/

JIMÉNEZ-RABIELA， Homero, VÁZQUEZGONZÁLEZ, Benjamín, ALVAREZMIRANDA, Gilberto Domingo y BARRAGÁN-SANTIAGO, Israel. Simulación de un Mecanismo de Línea Recta. Revista de Sistemas Computacionales y Tics. 2017, 3-8:4653.

Laravel. (19 de 04 de 2019). Retrieved from https://www.ecured.cu/Laravel

López Vélez, A., \& Aguilar Gómez, J. M. (2019). Modelo matemático de optimización multi-objetivo para el diseño de una red de distribución verde de ciclo cerrado para empresas de productos alimenticios no perecederos de consumo masivo. 
MIRÓN-CHACÓN, María José, SÁNCHEZMEDEL, Luis Humberto, CEPEDAMORALES, Ismael Habacuq, YOBALCASTRO, Sofía. Desarrollo de un sistema con aplicación móvil vinculada a un sensor de presión en volante como herramienta ante secuestros y robo en vehículos. Revista de Sistemas Computacionales y TIC'S 2017, 3-9:16.

OCHOA - ORNELAS, R., CERVANTES ZAMBRANO, F., GONZÁLEZ FRANCO, B., \& OCHOA-VÁZQUEZ, J. (2016) Implementación de aplicaciones con acceso a datos remotos (RDA). Revista de Estrategias del Desarrollo Empresarial, 23. From ECORFAN Database.

Oracle.com. (2017). MySQL | La base de datos de código abierto más popular | Oracle América Latina. [online] Available at: https://www.oracle.com/lad/mysql/index.html [Accessed 7 Jul. 2017].

Pardo, B. A. P., Garzón, I. D. S., \& Heredia, V. A. H. (2016). El software libre: $\iota$ fin de la propiedad individual. Revista Inventum, (18), 913.

Pedraza,

L.F. Pedraza, C.A. Hernández, D.A. López Control de tráfico vehicular usando ANFIS Ingeniare, 20 (1) (2012), pp. 79-88 April.

PHP. (19 de 04 de 2019). Retrieved from https://www.redgrafica.com/El-lenguaje-deprogramacion-PHP

Python. (15 de 04 de 2019). Retrieved from https://lenguajesdeprogramacion.net/python/

RAMÍREZ-ARIAS, Jesús Marcelo y HERNÁNDEZ, Talhia. La implantación de sistemas de información y la madurez organizacional. Revista de Sistemas Computacionales y TIC'S 2017, 3-10: 1-12.

SALAZAR-VÁZQUEZ, Fernando, RUIZMARTÍNEZ, Julio, FLORES-AZCANIO, Nancy y RAMÍREZJUÁREZ, Juana. Los MOOC Vehículo de transmisión para la capacitación. Revista de Sistemas Computacionales y TIC'S 2016, 2-6: 22-28.
Secretaría de Movilidad de Bogotá. "Manual de planeación y diseño para la administración del tránsito y el transporte". Tomo I, Capítulo 5, pp. 50-72. 2005.

Sehgal et al., 2010 V.K. Sehgal, S. Dhope, P. Goel, J.S. Chaudhry, P. SoodAn Embedded Platform for Intelligent Traffic Control.

SILBERSCHATZ, A., KORTH, H., \& SUDARSHAN, S. (2002). El modelo relacional. Madrid: McGrawHill.

Sistema Web, S. (22 de 04 de 2019). Retrieved from

https://www.ecured.cu/Sistema_informático

SWAV(Sistema Web de Apoyo a vehículos)Autores: Antonio Cañas, E. M. Ortigosa, Francisco Javier Fernández Baldomero, Mancía, E. Ros, María Begoña del Pino Prieto, P. A. Castillo de Castro, Informática educativa: nuevos retos, 2004, ISBN 8477236534.

VALDÉZ-MENCHACA, Alicia, CORTÉSMORALES, Griselda, VÁZQUEZ-DE LOS SANTOS, Laura y LEOS-QUINTANA, Andrea. Análisis del software utilizado para el repositorio de datos de una Arquitectura Empresarial. Revista de Sistemas Computacionales y TIC'S 2016.

VARGAS-MARTÍNEZ, M., Santiago, G. C., SANDOVAL-SÁNCHEZ, J., \& CASTILLOVALDEZ, G. (2016). Construcción de clusters de computadoras de bajo costo utilizando software libre. Revista de Sistemas Computacionales y TIC'S, 2(4), 19-25. From ECORFAN Database.

VILLALOBOS-ALONZO, María de los Ángeles, ROMO-GONZALES, Ana, LOPEZHERNANDEZ, Luis y MARQUEZSANCHEZ, María de los Ángeles. InnovaCapa: Software para el diagnóstico de capacidades en innovación enfocado a PyMES. Revista de Sistemas Computacionales y TIC'S 2016, 2-5: $1-8$. 
VILLALOBOS-ALONZO, María de los Ángeles, ROMO-GONZÁLEZ, Ana Eugenia, GUTIÉRREZ-GONZÁLEZ, Daniel, LÓPEZHERNÁNDEZ, Luis Manuel. Entorno WEB para el diagnóstico empresarial en investigación e innovación. Revista de Sistemas Computacionales y Tics. 2017, 3-9: 35-50. 